\title{
SISTEM KONTROL PENERANGAN MENGGUNAKAN ARDUINO UNO PADA UNIVERSITAS ICHSAN GORONTALO
}

\author{
Bahrin \\ bahrindahlan@gmail.com \\ Universitas Ichsan Gorontalo
}

\begin{abstract}
Abstrak
Dalam kehidupan sehari-hari, sadar atau tanpa kita sadari kita terus bertemu dengan suatu perangkat atau peralatan yang kerjanya terkendali secara otomatis baik terkendali sebagian maupun seluruhnya, sistem kendali adalah suatu alat atau kumpulan alat untuk mengendalikan, memerintah, dan mengatur keadaan dari suatu sistem, singkatnya, sistem yang digunakan untuk membuat suatu perangkat menjadi terkendali sesuai dengan keinginan manusia ini biasanya disebut sebagai sistem kendali, untuk mengatasi kesalahan manusia dalam mengatur penerangan yang ada di Universitas Ichsan Gorontalo seperti lupa mematikan lampu sehingga kurang efisien dalam penggunaan daya listrik yang dapat menyebabkan bertambahnya beban biaya univesitas ini, selain itu pula dengan menggunakan sakelar, sistem yang lama menjadi kurang aman dan memakan waktu untuk mematikan sebuah lampu mengingat gedung kampus bertingkat. Berdasarkan perangkat keras yang digunakan, maka ada 3 jenis simulasi yaitu simulasi analog, simulasi digital, dan simulasi hybrid. Penelitian ini diharapkan mampu menjadi solusi dari masalah yang dikemukakan diatas sehingga dapat mengendalikan penerangan secara efisien.Bahwa Sistem Kendali yang dirancang dapat digunakan. Hal ini dibuktikan dalam metode pengujian test case dengan pendekatan pengujian white box dan pengujian Blackbox pada rancangan sistem, sehingga sistem tidak dapat menerima input yang tidak tepat. Dari hasil pengujian test case diperoleh $C C=V(G)$ dimana $C C=7$ dan $V(G)=7$, hal ini menunjukkan bahwa penerapan pengujian sistem tersebut diatas dapat menghasilkan sistem dan proses looping (perulangan) pada flowchart yang membuat sistem menjadi lebih efektif.
\end{abstract}

Kata Kunci : Sistem Kendali, Simulasi, Arduino Uno, Flowhchart, looping.

\section{Pendahuluan}

Teknologi merupakan suatu sarana yang digunakan manusia untuk memenuhi kebutuhan mereka, beberapa teknologi saat ini merupakan perkembangan dari teknologi zaman dahulu yang sering digunakan dalam kegiatan sehari - hari. Oleh karena itu, perkembangan teknologi yang berubah menjadi teknologi masa kini telah berkembang pesat. Banyak teknologi yang dikembangkan sehingga lebih membantu manusia untuk memenuhi kebutuhannya. Salah satunya adalah teknologi komputer, pada awalnya computer digunakan layaknya mesin penghitung, karena kata computer sendiri berasal dari kata "to compute" yaitu untuk menghitung. Seiring waktu pun teknologi komputer yang dikembangkan bukan hanya sekedar mesin penghitung tapi juga mesin yang dapat memproses data. Saat ini di negara - Negara maju maupun negara - Negara berkembang computer banyak digunakan sebagai alat bantu di berbagai bidang, seperti dibidang kedokteran, militer, industri, penerbangan komersil, pendidikan dan lain - lain, hamper semua tempat bekerja di Indonesia menggunkan computer untuk membantu manusia dalam bekerja, misalnya di bidang militer, computer digunakan untuk mengendalikan pesawat pengitai tanpa awak atau yang lebih dikenal dengan istilah "drone" untuk mencari informasi lokasi musuh. Saat ini hamper di setiap rumah, instansi - instansi pemerintah dan swasta telah menggunakan teknologi komputer, tetapi masih banyak orang,khususnya di kabupaten pohuwato yang menggunakan teknologi computer ini sebatas media hiburan saja. Padahal jika dilihat dari fungsinya, teknologi computer ini sangat banyak manfaatnya misalnya dapat kita manfaatkan sebagai pengendali penerangan otomatis dengan bantuan mikrokontroller.

Univesitas Ichsan Gorontalo adalah salah satu universitas yang, dengan jumlah mahasiswa yang begitu banyak dan jurusan yang berbeda - beda maka kampus ini juga menyediakan fasilitas gedung kampus bertingkat dan ruangan kelas yang banyak, fasilitas ini adalah fasilitas utama yang sangat penting untuk menunjang kegiatan belajar dan mengajar. Kegiatan belajar dan mengajar dikampus ini tidak hanya berlangsung pada siang hari namum juga sampai malam hari, sehingga untukk elancaran proses belajar mengajar kampus ini membutuhkan penerangan pada saat kondisi malam hari dan juga pada saat cuaca mendung, tetapi untuk mengontrol penerangan ini masih 
menjadi kegiatan yang membuang waktu dan tenaga serta ada beberapa pengguna ruangan yang sering lupa mematikan lampu penerangan sehabis menggunakan ruangan, hal ini tentu tidak efisien dan cenderung merugikan. Sehingga hal ini yang menjadi acuan penulis untuk memanfaatkan teknologi computer tersebut sebagai alat yang dapat mengontrol sistem penerangan pada Universitas Ichsan Gorontalo .

Untuk mewujudkannya dibutuhkan sebuah sistem kontrol yang secara otomatis dapat bertindak sebagai pengatur penggunaan penerangan pada kampus tersebut, aplikasi yang akan dibuat untuk sistem ini adalah menggunakan bahasa pemograman Delphi dan untuk memprogram papan mikrokontroller penulis menggunakan bahasa pemograman $\mathrm{C}$ yang telah disederhakan menjadi bahasa pemograman C-Arduino serta Microsoft office Access sebagai database dari sistem ini. Adapun Penelitian ini diberi judul "Sistem Kontrol Penerangan Menggunakan Arduino Uno Pada Universitas Ichsan Gorontalo".

\section{Metode}

\subsection{Definisi Simulasi}

Simulasi adalah proses implementasi model menjadi program komputer (software) atau rangkaian elektronik dan mengeksekusi software tersebut sedemikian rupa sehingga perilakunya menirukan atau menyerupai sistem nyata (realtitas). Jadi simulasi adalah proses merancang model dari suatu sistem yang sebenarnya, mengadakan percobaan - percobaan terhadap model tersebut (Irvan Febriansyah, 2010: 9).

Berdasarkan perangkat keras yang digunakan, maka ada 3 jenis simulasi yaitu simulasi analog, simulasi digital, dan simulasi hybrid. Simulasi analog adalah simulasi yang implementasinya menggunakan rangkaian elekronika analog seperti OpAmp (operational ampflifier) untuk integrasi, pembanding, pembalik, penjumlah dan lain - lain. Simulasi digital adalah simulasi yang mana implementasinya menggunakan komputer digital. Simulasi hybrid adalah simulasi yang mana implementasinya menggunakan gabungan rangkaian elektronik analog dan komputer digital. (Irvan Febriansyah, 2010: 9).

\subsection{Konsep Dasar Kontrol}

Menurut Erinofiardi (2012:261), Suatu sistem kontrol otomatis dalam suatu proses kerja berfungsi mengendalikan proses tanpa adanya campur tangan manusia(otomatis).

Konsep dasar pengontrolan sudah ada sejak abad-18 yang dipelopori James Watt yang membuat kontrol mesin uap, Nyquis (1932) membuat sistem pengendali uang tertutup, Hazem (1943) membuat servo mekanik dan masih banyak yang lainnya.Kontrol otomatis mempunyai peran pentingdalam dunia industri modern saat ini. Seiring perkembangan kemajuan ilmupengetahuan dan teknologi, sistem kontrol otomatis telah mendorong manusiauntuk berusaha mengatasi segala permasalahan yang timbul di sekitarnya dengancara yang lebih mudah, efisien dan efektif. Adanya kontrol otomatis secaratidak langsung dapat menggantikan peran manusia dalam meringankan segalaaktifitasnya.

Sedangkan untuk fungsi kendali itu sendiri (Irvan Febriansyah, 2010: 33) meliputi :

a. Menerima input dan output referensi (sesuai dengan tingkah laku sistem yang diinginkan).

b. Menerima informasi output melalui elemen baik dan membandingkan dengan output mengambil suatu keputusan melalui perhitungan-perhitungan yang cukup rumit.

Dilihat dari prinsipnya, fungsi dasar suatu kendali adalah mencakup operasi pengukuran, perbandingan, perhitungan dan koreksi. Dimana pengukuran merupakan operasi otomatisasi penafsiran mengenal suatu proses dikontrol oleh sistem. Perbandingan merupakan pengujian kesetaraan antara nilai yang diukur dengan yang diharapkan (Irvan Febriansyah, 2010: 34).

Perhitungan akan memberikan keyakinan yang menunjukkan seberapa besar perbedaan antara nilai yang diukur dengan nilai yang diharapkan. Sedangkan koreksi merupakan penentu langkah pengaturan untuk mengurangi perbedaan antara hasil yang diukur dengan nilai yang diharapkan kendali dapat disebut sebagai prosedur yang bisa mempunyai pengaruh terhadap hasil akhir suatu proses atau operasi (Irvan Febriansyah, 2010: 34).

Kendali terhadap waktu atau respon merupakan variabel yang tergantung jenis aplikasi merupakan faktor yang cukup berarti yang mempunyai pengaruh langsung terhadap keefektifan hasil akhir (Irvan Febriansyah, 2010: 33).

Menurut beberapa teori diatas dapat disimpulkan bahwa pengontrolan adalah pengendalian suatu proses sistem kerja yang dapat dikendalikan sesuai dengan keinginan manusia dalam mengerjakan segala aktivitas. 
Sistem kontrol berdasarkan cara kerjanya dapat di bagi menjadi dua bagian, yaitu sistem kontrol loop terbuka dan sistem kontrol loop tertutup (Irvan Febriansyah, 2010: 34).

Metode yang digunakan dalam sistem control penerangan ini adalah metode simulasi yaitu metode penelitian yang bertujuan untuk mencari gambaran melalui sebuah system berskala kecil atau sederhana (model) dimana di dalam model tersebut akan dilakukan manipulasi atau control untuk melihat pengaruhnya. Penelitian ini membutuhkan lingkungan yang benar-benar serupa dengan keadaan atau sistem yang asli.

Menurut Saptaji (2015:23) Arduino Merupakan papan elektronik berbasis mikrokontroller ATMega yang memenuhi sistem minimum mikrokontroller agar dapat bekerja secara mandiri (standalone controller). Menurut Feri Djuandi (2011:8) Komponen utama didalam papan Arduinoadalah sebuah mikrokontroler 8 bit dengan merk ATMega yang dibuat oleh Atmel corporation. Berbagai papan Arduinomenggunakan tipe Atmega yang berbeda - beda tergantung dari spesifikasinya, sebagai contoh Arduino Uno menggunakan ATmega328 sedangkan Arduino Mega 2560 yang lebih canggih menggunakan ATmega2560.

Dalam penelitian ini penulis menggunakan papan mikrokontroller arduino tipe arduino uno yang menggunakan chip Atmega 328.

\subsection{Bagian - bagian papan mikrokontroller arduino}

Saptaji (2015:38) menjelaskan pada papan arduino uno terdapat bagian - bagian antara lain ialah seperti terlihat pada gambar berikut:

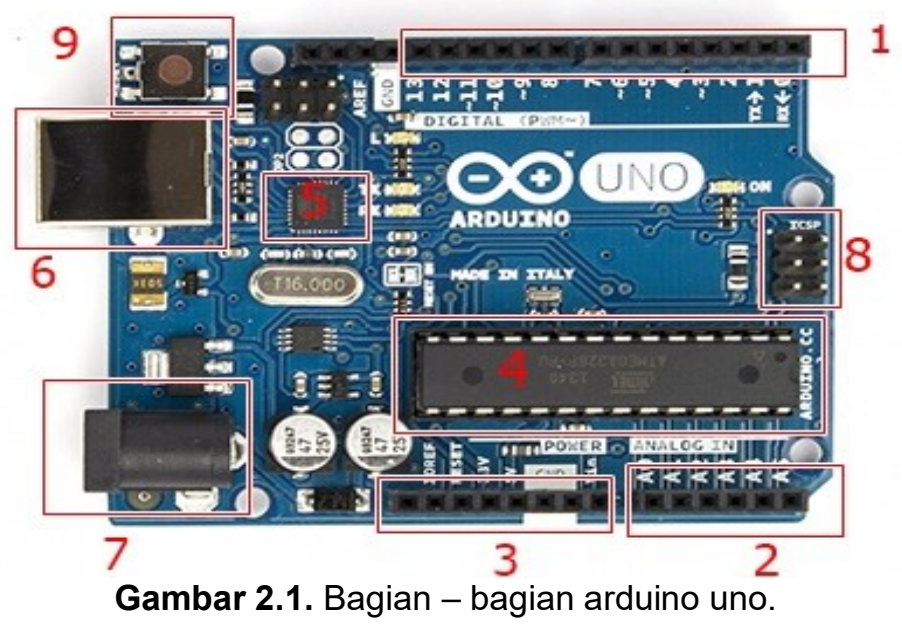

1. Pin input/output digital (diberi Label '0 sampai 13')

Secara umum pin $1 / O$ ini adalah pin digital, yakni pin yang bekerja pada level tegangan digital (0V sampai $5 \mathrm{~V}$ ) baik untuk input atau output.namaun pada bebrapa pin output analog, yang dapat mengeluarkan tegangan analog $0 \mathrm{~V}$ sampai $5 \mathrm{~V}$, pin tersebut adalah pin 3,5,6,9,10 dan 11 , selain itu untuk pin 0 dan 1 juga memiliki fungsi khusus sebagai pin komunikasi serial.

2. Pininput analog(diberi Label 'A0 sampai A5').

Pin tersebut dapat memrima input tegangan analog antara $0 \mathrm{~V}$ sampai $5 \mathrm{~V}$, tegangan ini akan direpresentasikan sebagai bilangan 0 - 1023 dalam program.

3. Pin untuk sumber tegangan

Kelompok pin ini merupakan kumpulan pin yang berhubungan dengan sumber tenaga, missalnya output $5 \mathrm{~V}$, Output $3,3 \mathrm{~V}$, GND (2 pin) dan Vref (tegangan referensi untuk pembacaan ADC internal)

4. IC ATMega328

Seperti yang telah dijelaskan IC ini bertindak sebagai pusat kendali pemrosesan data.

5. IC ATMega16U

IC ini deprogram untuk menangani komunkasi data dengan PC melalui port USB.

6. Jack USB

Merupakan soket USB tipe B sebagai penghubung data serial dengan PC.

7. Jack Power

Merupakan Soket untuk catu daya eksternal antara 9V samai 12V DC.

8. Port ICSP (In-Circuit Serial Programing)

Port ini digunakan untuk memprogram arduino tanpa bootloader.

9. Tombol Reset 
Digunakan untuk mereset papan mikrokontroller arduino untuk memulai program dari awal.

\section{Hasil dan Pembahasan}

3.1. Konfigurasi Pin Arduino uno

Saptaji (2015:40) memberikan gambaran bahwa terdapat konfigurasi pin papan mikrokontroller arduino uno seperti pada gambar berikut.

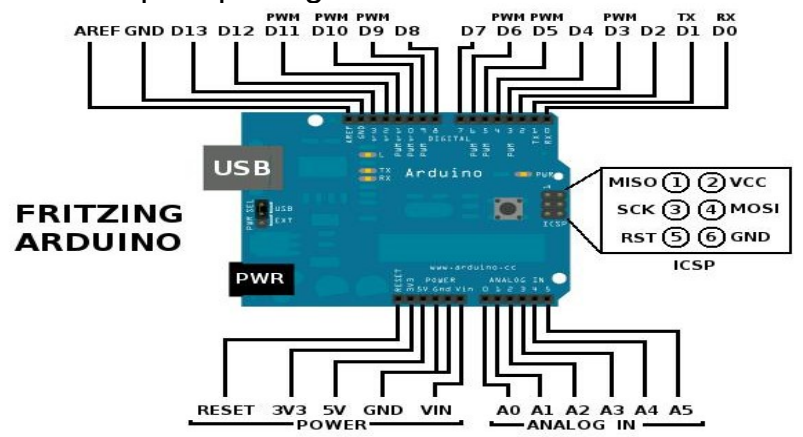

Gambar 3.1. Konfigurasi pin arduino uno.

Jadi sebenarnya Arduino adalah minimum sistem dari mikrokontroller ATMega328 yang di buat sedemikian rupa dan sederhana sehingga memudahkan dalam memprogram dan mengimplementasikannya khususnya memudahkan penulis dalam penelitiannya.

\subsection{Pengujian White Box}

White box testing adalah metode desain test case yang menggunakan struktur kontrol desain prosedural untuk mendapatkan test case.

Pengujian ini dilakukan dengan membuat uji coba kasus yang benar dan kasus yang salah dan mengamati reaksi perangkat lunak yang dibuat apakah sudah sesuai dengan spesifikasi yang dibutuhkan.

Dengan kata lain pengujian ini berbeda dari pengujian dengan metode white box dimana pengujian ini diharapkan mampu mrngungkapkan kelas kesalahan yang lebih luas, pegujian dengan metode ini lebih difokuskan untuk menemukan kesalahan dalam beberapa kategori, diantaranya :

a. fungsi-fungsi yang tidak benar atau hilang

b. kesalahan interface

c. kesalahan dalam struktur data atau akses database eksternal

d. kesalahan kinerja

e. inisialisasi dan kesalahan terminasi.

Flowchart Matriks Keputusan 


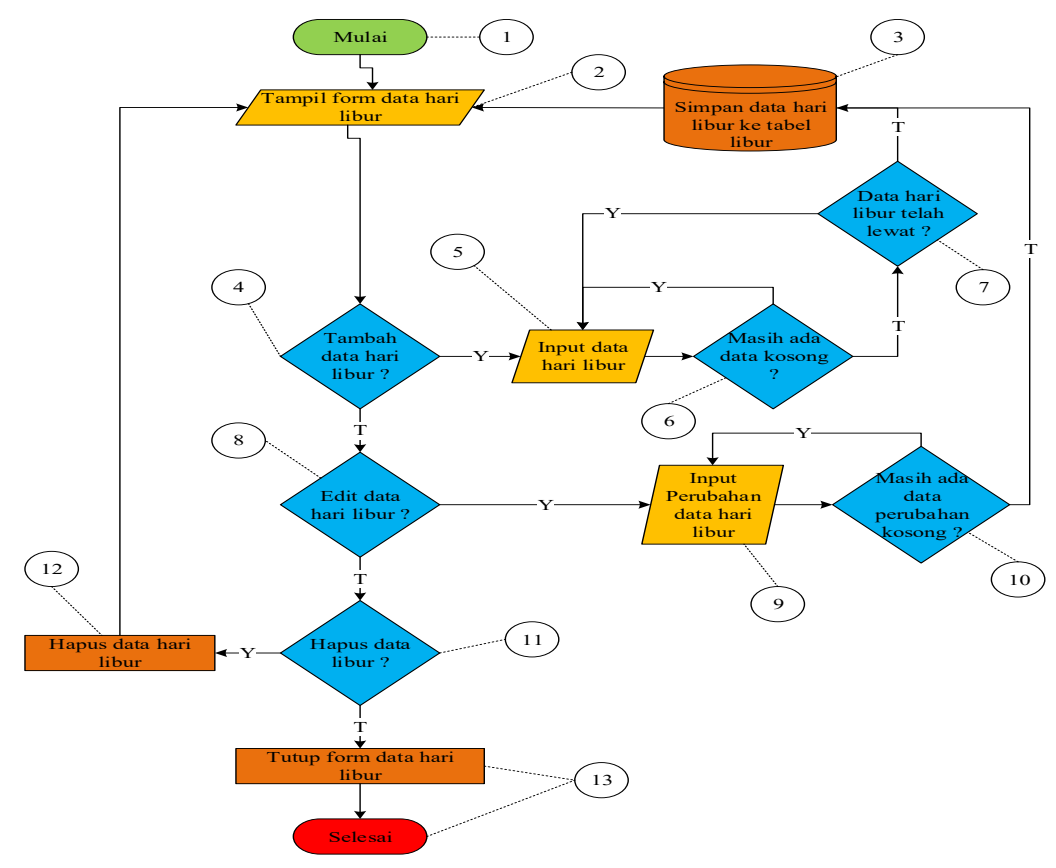

Gambar 3.2 Flowchart Pengujian White Box

Dari flowchart diatas, maka diperoleh :
Region
(R)
$=7$
Node
(N) $=13$
Edge
(E) $\quad=18$
Predicate Node
P) $\quad=6$
Maka, V
(G) $\quad=\mathrm{E}-\mathrm{N}+2$
$=18-13+2$
$=7$
Maka, V (G)
$=P+1$
$=6+1$
$=7$
Dan, Cyclomatic Complexity
$=\mathrm{R} 1, \mathrm{R} 2, \mathrm{R} 3, \mathrm{R} 4, \mathrm{R} 5, \mathrm{R} 6, \mathrm{R} 7=7$

1) Form ComPort Setup

Form ini digunakan untuk mengatur atau mengkonfigurasi serial port yang digukanan untuk mengirim dan menerima data serial antara arduino uno dan komputer.

\begin{tabular}{|c|c|c|}
\hline & Setup & $x$ \\
\hline \multicolumn{3}{|l|}{ Settings } \\
\hline \multirow{7}{*}{$\begin{array}{l}\text { Port } \\
\text { Baud rate } \\
\text { Data bits } \\
\text { Stop bits } \\
\text { Parity } \\
\text { Flow control }\end{array}$} & COM13 & $\checkmark$ \\
\hline & 9600 & $\checkmark$ \\
\hline & 8 & $\checkmark$ \\
\hline & 1 & $\checkmark$ \\
\hline & None & $\checkmark$ \\
\hline & None & $\checkmark$ \\
\hline & OK & Cancel \\
\hline
\end{tabular}

2) Form Kontrol

Gambar 3.3. Form ComPort Setup

Setelah pengaturan Serial selesai maka akan tampil Form Kontrol, form Kontrol merupakan form yang berfungsi sebagai monitor keadaan lampu pada setiap ruangan kelas. 


\section{3) Form Login}

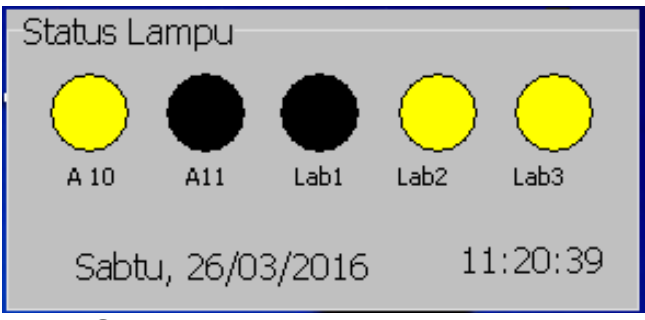

Gambar 3.4. Form kontrol

Form ini berfungsi untuk memasukan password dari sistem. Pada form login ini hanya admin yang diberi hak akses. Dan bersifat single user. Password atau Kata Sandi secara default adalah "admin" dan dapat dirubah dengan menekan tombol ganti password.

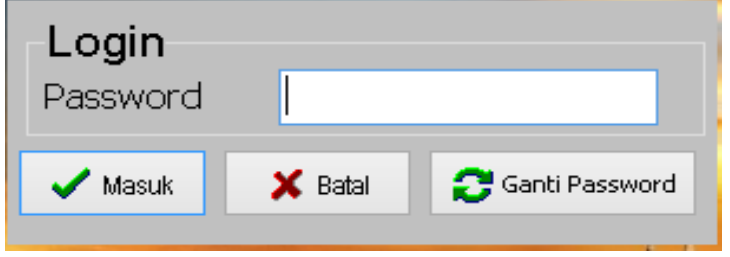

4) Form ganti password

\section{Gambar 3.5. Form Login}

Form ini berfungsi untuk mengganti password dari sistem. Form ini akan meminta password yang lama kemudia password yang baru, apabila password yang lama sesuai maka password yang baru akan disimpan ke database.

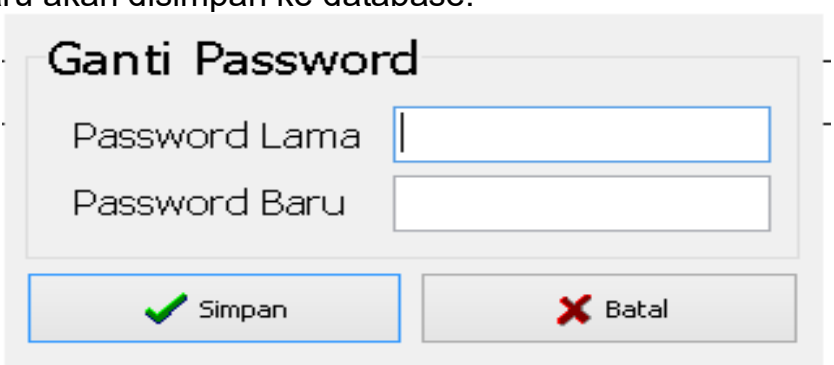

Gambar 3.6. Form ganti Password

5) Form jadwal

Setelah berhasil login maka akan tampil form jadwal, form ini berfungsi untuk menampilkan jadwal yang tersimpan dan bisa juga untuk mengedit jadwal. Form ini terdapat sebuah list box yang berisi nama-nama hari yang dapat dipilih sesuai dengan hari yang akan di tampilkan atau di edit jadwalnya. 


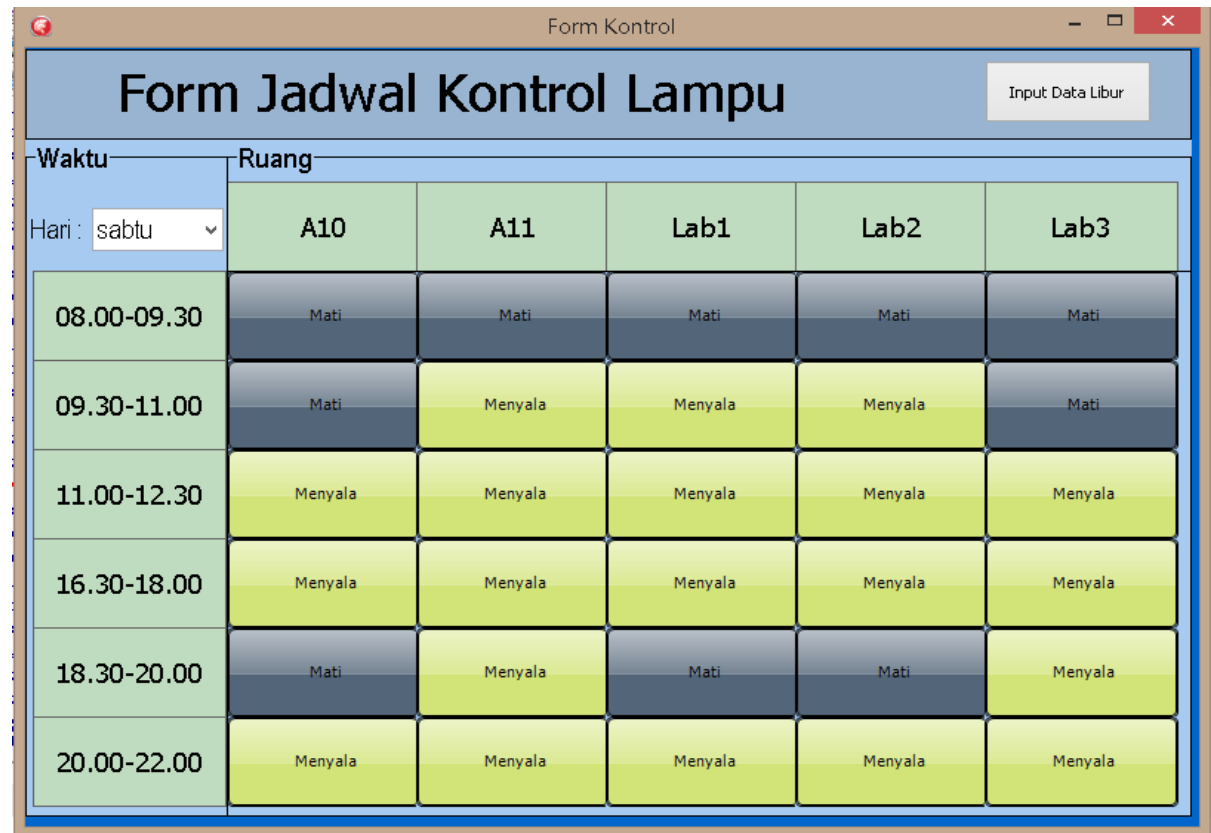

\section{6) Form input data libur}

\section{Gambar 3.7. Form Jadwal}

Form input libur ini berfungsi untuk memasukan data libur kedalam sistem, jika sistem menemukan subuah tanggal dalam database maka akan dibandingkan dengan tanggal sistem komputer jika cocok maka semua lampu akan dimatikan.

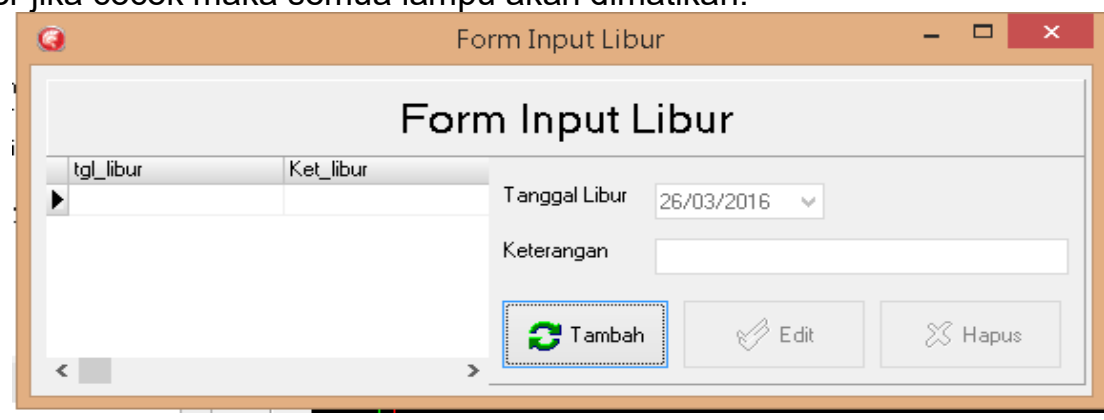

Gambar 3.8. Form input libur

\section{Kesimpulan dan Saran}

Berdasarkan hasil penelitian yang dilakukan pada Universitas Ichsan Gorontalo yang telah diuraikan sebelumnya, maka dapat diambil kesimpulan sebagai berikut, bahwa :

1. Dalam Simulasi Sistem Kontrol ini dihasilkan dapat mengatasi masalah lupa mematikan sakelar sehingga lebih efisien dalam menggunkan listrik.

2. Sistem ini dapat memberikan keamanan karena sistem ini tidak secara langsung kontak dengan manusia melalui sistem kontrol penerangan ruangan ini.

3. Simulasi Sistem Kontrol Penerangan yang dirancang dapat diimplementasikan. Hal ini dibuktikan dalam metode pengujian test case dengan pendekatan pengujian white box dan pengujian Blackbox pada rancangan sistem, sehingga sistem tidak dapat menerima input yang tidak tepat. Dari hasil pengujian test case diperoleh $C C=V(G)$ dimana $C C=$ 7 dan $V(G)=7$, hal ini menunjukkan bahwa penerapan pengujian sistem tersebut diatas dapat menghasilkan sistem dan proses looping (perulangan) pada flowchart yang membuat sistem menjadi lebih efektif.

Berikut adalah saran - saran yang diharapkan dapat memperbaiki sistem ini, sehingga dapat di implementasikan dengan baik :

1. Sistem ini masih terlalu sederhana sehingga membutuhkan pengembangan yang cukup signifikan, munggkin kedepan bisa menambahkan berbagai jenis sensor seperti sensor PIR (passive infra red) dan lain sebagainya sehingga sistem ini lebih akurat dan fleksibel. 
2. Penampang LDR (light dependent resistor) yang di gunakan dalam sistem ini masih terlalu kecil sehingga dapat di ganti dengan LDR (light dependent resistor) yang berpenampang lebih besar.

3. Untuk lebih efisien, perangkat pengendali bisa menggunkan komponen - komponen yang lebih kecil atau komponen - komponen SMD (surface mount device) serta menghilangkan komponen IC (integrated circuit) 7805 karena Arduino Uno dan relay dapat di suplay hanya dengan tegangan DC 5 Volt tanpa perlu menurunkan tegangan dari adaptor 12 Volt. Relay pada perangkat pengendali dapat diganti dengan SSR (solid state relay) agar lebih awet.

\section{Ucapan Terima Kasih}

1. Ibu Dr. Hj. JURIKO ABDUSSAMAD. M.Si SelakuKetua Yayasan Pengembangan dan IImu Pengetahuan dan Tekhnologi (YPIPT) Ichsan Gorontalo.

2. Bapak DR. ABDUL GAFFAR LATJOKE, M.Si. Selaku Rektor Universitas Ichsan Gorontalo.

3. Ibu ZOHRAHAYATY, M.Kom, Selaku Dekan Fakultas IImu Komputer Universitas Ichsan Gorontalo.

\section{Daftar Pustaka}

[1]. A. S, Rosa dan M. Shalahuddin. 2013. Rekayasa Perangkat Lunak. Yogyakarta :Informatika.

[2]. Amikom. Pengenalan Software Proteus. (http://elearning.amikom.ac.id/ index.php/ download/ materi / 190302181-ST014-56/ 2015/03/20150301_PENGENALAN \% 20SOFTWARE \% 20 PROTEUS.pdf diakses 15 September 2015).

[3]. Bina Saranalnformatika. 2010. Modul Praktek laboratorium Komputer Borland Delphi. Jakarta : Bina Saranalnformatika.

[4]. Budiharto, Widodo. 2009. 10 Proyek Robot Spektakuler. Jakarta: PT. Elex Media Komputindo.

[5]. Djuandi, Feri. 2011. PengenalanArduino: (https//:tobuku.com diakses 21 Juni 2015).

[6]. http://www.dominicdube.com/blog/arduino-uno-rev3-pinout/diakses 30 Agustus 2015.

[7]. Saptaji, Handayani W. 2015. Mudahbelajar Mikrokontroller dengan Arduino. Bandung :Widya Media.

[9]. Rusmadi, Dedy. 2009. MengenalKomponenElektronika. Bandung: Pionir Jaya.

[10]. Nugroho, 2005, Analisis dan Perancangan Sistem Informasi dengan Metodologi berorientasi Objek, Bandung : Informatika

[11]. Narbuko, Cholid, 2001. Metodologi Penelitian. Bumi Aksara, Jakarta

[12]. Pressman, R.S., 2002, Rekayasa Perangkat Lunak: Pendekatan Praktis (Buku I), Yogyakarta : Andi

[13]. Supardi, Yuniar, 2011, Menjadi Programer VB 6.0 Hingga VB 2008, Jakarta : $\quad$ Elex Media Komputindo.

[14]. Turban \& Aronson, 2005, Edisi 7. Decision Support Systems and Intelligent Systems, Yogyakarta : Andi

[15]. Whitten, et all. 2004. Metode Analisis dan Desain Sistem. 